\title{
Calcium-Responsive Transactivator
}

National Cancer Institute

\section{Source}

National Cancer Institute. Calcium-Responsive Transactivator. NCI Thesaurus. Code C97805.

Calcium-responsive transactivator (396 aa, $43 \mathrm{kDa}$ ) is encoded by the human SS18L1 gene. This protein plays a role in transcriptional activation. 